\title{
MEAN-TYPE MAPPINGS AND INVARIANCE PRINCIPLE
}

\author{
JANUSZ MatKowsKi AND PAWEŁ PASTECZKA
}

Abstract. In the finite dimensional case, mean-type mappings, their invariant means, relations between the uniqueness of invariant means and convergence of orbits of the mapping, are considered. In particular it is shown, that the uniqueness of an invariance mean implies the convergence of all orbits. A strongly irregular mean-type mapping is constructed and its unique invariant mean is determined. An application in solving a functional equation is presented.

Mathematics subject classification (2010): Primary 26E60, 39B22; Secondary 39B12.

Keywords and phrases: Means, mean-type mapping, invariant mean, functional equation, iteration, orbit.

\section{REFERENCES}

[1] J. M. Borwein, P. B. Borwein, Pi and the AGM - a Study in Analytic Number Theory and Computational Complexity, John Wiley \& Sons, New York, 1987.

[2] B. DeręGOWska, P. PASteczKa, Quasiarithmetic-type invariant means on probability space, arXiv:2005.02063 [math.FA] (2020).

[3] M. Kuczma, An introduction to the theory of functional equations and inequalities. Cauchy's equation and Jensen's inequality, Prace Naukowe Uniwersytetu Śląskiego w Katowicach [Scientific Publications of the University of Silesia], 489. Uniwersytet Śląski, Katowice; Państwowe Wydawnictwo Naukowe (PWN), Warsaw, 1985.

[4] J. MATKOWSKI, Iterations of mean-type mappings and invariant means, European Conference on Iteration Theory (Muszyna-Złockie, 1998). Ann. Math. Sil. No. 13 (1999), 211-226.

[5] J. MATKOWS KI, Iterations of the mean-type mappings, Iteration theory (ECIT '08) Grazer Math. Ber., 354, Institut für Mathematik, Karl-Franzens-Universität Graz, 2009. 158-179.

[6] J. MATKOWS KI, Iterations of the mean-type mappings and uniqueness of invariant means, Ann. Univ. Sci. Budapest. Sect. Comput. 41 (2013), 145-158.

[7] J. MATKOWSKI, P. PASTECZKA, Invariant means and iterates of mean-type mappings, Aequationes Math. 94 (2020), 405-414.

[8] P. PasteczKa, Invariant property for discontinuous mean-type mappings, Publ. Math. Debrecen. 94 (2019), 409-419.

[9] G. Toader, I. Costin, Means in Mathematical Analysis. Bivariate Means, Mathematical Analysis and Its Applications, Academic Press, London, 2018. 